\title{
Research on the Innovation of Shaanxi's Higher Education Teaching Model Based on Internet
}

\author{
Fengxiang Jiang*
}

*Business Department, Xi’ an Peihua University, Xi’ an Shannxi,China 710125

Keywords: Internet; Shaanxi Universities and Colleges; Education and teaching Mode

\begin{abstract}
Internet has changed the way of life and brought out the reform of traditional industries since the human being entered into the information era. Education has great changes, especially the higher education. All Chinese universities and colleges are facing opportunities and challenges. Universities and Colleges in Shaanxi province occupy an important position in the national power of education. In the context of the Internet, Shaanxi higher education teaching mode is facing the necessity of deepening reform, the learning characteristics and learning mode of the new age population has undergone major changes, Shaanxi universities should follow the development trend of the times, vigorously develop the online course. But due to various constraints, Shaanxi University online course development is not very mature, it is difficult to effectively improve the learning efficiency, it is difficult to adapt to the current needs the reform of education and teaching in Colleges and universities. Therefore, colleges and universities in Shaanxi should make full use of the Internet platform, the construction of high quality curriculum resources, promote teaching mode reform. This paper first analyzes the importance of education and teaching reform in Colleges and universities in Shaanxi under the environment of Internet, and then build path under the Internet environment Shaanxi university innovation education teaching mode and puts forward the safeguard measures.
\end{abstract}

\section{Introduction}

Internet makes the innovation of knowledge society. The Internet has changed the mode of development in the traditional industry with a flat, decentralized, self-organizing feature, can promote the relations of production and the production of deconstruction and reconstruction. Similarly, the Internet has changed the mode of education and teaching in Colleges and universities, education resource sharing movement in every corner of the world, to the disseminate of knowledge, "the Internet" of higher education has become the focus of the society. While the size and distribution of China's higher education is not balanced to high-quality education resources did not play the ultimate role, and because the Internet has changed people's idea and mode of learning, lifelong learning concept of the people, only the Internet can meet the growing higher the demand of education. The massive open online courses called MOOCs have been across the field of global higher education since 2012.A network course is different from the traditional teaching mode. Anyone can access the Internet with almost no restrictions after the number of broadband network development and wide application of intelligent mobile phone and mobile technology. You can use the Internet tools to receive higher education. Colleges and universities have blended teaching ways, including the flipped classroom, micro education course of new teaching mode, which reconstructs the teaching process and teacher-student relationship. Online education has achieved some success since our country since the Ministry of Education launched a pilot project of open education in 1999, we must reconstruct the mode of education and teaching owing to the lack of network teaching mode. The development of open online 
courses in Colleges and universities in Shaanxi is less than the number of schools, the enthusiasm of students using online open courses is not high, hinders the further development of Shaanxi online open courses.

\section{The Importance of Education and} Teaching Reform in Colleges and Universities in Shaanxi under the Environment of Internet

\subsection{To promote education and teaching resources with Internet overcoming time and space constraints}

That College students rely on the network is far beyond people's imagination. At the same time, the Internet provides the most extensive teaching resources for human beings. Therefore, Shaanxi universities can make full use of Internet technology to create a new mode of education, enriching curriculum information resources construction, such as curriculum courseware, lesson plans, teaching plan, teaching case, case teaching way, database, video, picture material and other types of theme resources. Because the Internet learning overcomes the time and space constraints, and the on-line classroom with the rich teaching resources can make knowledge more attractive, which can attract students.

\subsection{To stimulate students' autonomous} learning and improve teaching effectiveness

In the internet environment the teaching resources is rich, which can meet the learning needs of students under the guidance of teachers, can take the initiative to use the network teaching resources. The teaching resources in the network is abundant, teachers can skillfully create all kinds of situations, stimulating students' thinking, stimulating students' active learning. Therefore, students can have a deep understanding of the cognition and theory of course, so as to improve the students' confidence of learning into active learning model, to improve the effectiveness of classroom teaching.

2.3 We can realize the sharing of high-quality curriculum resources with the help of the Internet platform

The economic development level of western region is low in Shaanxi, and for the lack of construction investment of educational information resources, so the education resources sharing information platform construction is lagging behind, and the teaching information platform model is single, the character is not obvious, cannot effectively support the routine teaching, and curriculum integration is not high, cannot reflect the subject characteristics, regional characteristics, but also education sharing cannot support high-quality resources. With the development of computer network technology and multimedia technology, sharing education resources can provide high-quality teaching resources for learning in Campus Internet, which has become possible and inevitable trend. Therefore, Shaanxi universities can use the Internet platform, to make full use of the resource sharing platform and realize the sharing of high quality teaching resources in the world.

\section{The path of Constructing Innovative} Teaching Mode in Shaanxi under the Internet Environment

Under the Internet environment, the future of the Internet education will also be multipolar. Based on the Internet, great changes have taken place in learning mode, forming multi polarization of the internet teaching mode, emphasizing the combination of online and offline, student feedback problems teachers through online, online and offline guidance; constantly improve the network learning environment and learning content, teachers and students to achieve information interactive.

\section{1 pay attention to the teaching of 020} mode, the realization of online learning and offline inquiry flipped classroom model

The Internet technology gave birth to the reform of education and teaching. Not only to ground the traditional educational dimension in the Internet era, but also the need to respect the students "Internet users" identity, education teaching reform should be imprinted on the Internet thinking. To build the network teaching platform, online and offline by speaking, training, testing, evaluation, test five teaching elements. The extension of classroom teaching in five aspects: curriculum preparation, course work, extracurricular reading, extracurricular discussion, mid-term examination, 
ensure the effectiveness of learning.

\subsection{To strengthen the construction of} high-quality online curriculum resources, to achieve high-quality curriculum resources sharing

Shaanxi universities should gradually open concept, change the understanding, strengthen the network of high quality curriculum resources library construction, build a high-quality curriculum resources sharing platform, and the resources construction should combine closely with teaching practice. To accelerate the formation of new curriculum, encourage research and development of research learning course, optional courses, technical courses, and community service the emerging field of social practice courses, in addition to set the appropriate theme, the corresponding curriculum resources is to get the most important, and even set up the theme of development also depends on the curriculum resources. Network curriculum resources mainly include the teaching resources and learning resources, curriculum theory knowledge and skills curriculum discussion, the development of online examination system; auxiliary teaching resources include material library, exercises, case library, the library, courseware, teaching plans, problems of network course in the highlights. During the construction process of the resource bank, to unify the protection of intellectual property rights and open sharing; encourage diversification and avoid repeated unified development; actively guide the unified recommendation and use market mechanism. To establish an exchange mechanism in various forms is to realize the sharing of various forms; to build the dynamic development mechanism of self-improvement.

\section{Constructing the safeguard measures of} the innovation education in Shaanxi Universities under the Internet Environment

Under the Internet environment of Shaanxi university innovation education and teaching, teachers should speed up the construction of network curriculum, strengthen the construction of teachers, teacher training will be combined with the online teaching, this is the construction of Shaanxi college network teaching resources sharing mechanism of teachers, advanced education theory, teachers should be modernized to enhance learning, to master basic skills the network course construction; at the same time, the construction of network teaching platform is the foundation for promoting the construction of network curriculum, and the construction of the network teaching platform aims to realize the teaching innovation through the transmission network education information resources sharing, can form a kind of ideal of Multimedia network teaching environment, to strengthen the construction of network curriculum resources sharing platform. It also needs to pay attention to the construction of network; curriculum resources investment, setting up the network curriculum resources construction of special funds, to encourage more high-quality curriculum resources.

In short, the teaching reform of online courses in Colleges and universities in Shaanxi should do in-depth research in the integration of Internet. Education uses the Internet as a platform and tools, the positive development of online education, to improve the innovative education and teaching management mechanism of school education innovation, constructing the design and development of the excellent network courses, the teaching operation team, continuing to develop high-quality online curriculum resources, to improve the practicability and the attraction of the course, but also need to continue to explore the online education mode of operation, in order to meet demand for education in the new era.

\section{References:}

[1] Guo Yun, Bai Lin. Research on the Innovation of Ideological and Political Education in Colleges and Universities under the Network Environment [J]. Modern Educational Science, 2014 (06): 61-64/69

[2] Chen Jianghua, Nie Yong, Huang Xiao. Under the Network Environment on the Mode of Flipping the Classroom PBL [J]. China Education Information, 2015 (4): 18-21.

[3] Liang Tingting. Research and Practice of Micro Course Design and Flipped Classroom Based on PBL [J]. Journal of Guangxi Normal University for Nationalities, 2016, 33 (PBL): 34-37.

[4] Hu Lihua. The Reform and Innovation of Regional 
Higher Continuing Education under the Guidance of Internet Education [J]. Shaanxi Education: Higher Education, 2016 (6): 32-34.

[5] Zhang Hongwei, Wang Chunming, Wang Li. The Innovation and Practice of the Support System of the Super Fusion Continuing Education Under the Perspective of "Internet" [J]. Chinese Adult Education, 2016 (13): 142-145.

\section{Profile of the Author:}

Fengxiang Jiang (1983.07-), female, Institution of Business, Xi'an Peihua University, Lecturer, research interests: Regional Economics, Human Resource Management and Entrepreneurship Education 